Dunamis: Jurnal Teologi dan Pendidikan Kristiani

Volume 5, Nomor 1 (Oktober 2020)

ISSN 2541-3937 (print), 2541-3945 (online)

http://www.sttintheos.ac.id/e-journal/index.php/dunamis

DOI: 10.30648/dun.v5i1.301

Submitted: 30 Januari 2020

Accepted: 3 Juni 2020

Published: 29 September 2020

\title{
Evaluasi Struktur Internal Dimensions of Grace Scale (DGS)
}

\author{
Devin Sandy Putra; Lina Natalya; Ide Bagus Siaputra* \\ Fakultas Psikologi Universitas Surabaya \\ std@staff.ubaya.ac.id*
}

\begin{abstract}
Grace is the main and foremost construct in Christian life whose existence cannot be empirically measured. Nevertheless, Bufford, Sisemore, and Blackburn (2017) succeeded in developing a scale that can measure Christian's experience, belief, and attitudes towards grace called Dimensions of Grace Scale (DGS). The purpose of this research was to evaluate the internal structure of DGS using Exploratory Factor Analysis (EFA) and reliability analysis. The DGS scale was translated into Indonesian language and distributed to 401 Christians over 17 years of age. The DGS scale has five dimensions which are Experiencing God's Grace, Costly Grace, Grace to Self, Grace from Others, and Grace to Others. However, the EFA shows that six factors are the best grouping for DGS. Moreover, Costly Grace dimension was separated into two dimensions that are Grace and Responsibility and Graceful Avoidance of Personal Legalism, in line with Costly Grace theory.
\end{abstract}

Keywords: Exploratory Factor Analysis; grace; common grace; special grace; cheap grace; costly grace

\begin{abstract}
Abstrak
Kasih karunia merupakan sebuah kontruk utama di dalam kehidupan orang Kristen yang keberadaannya tidak sepenuhnya bisa diukur. Namun, Bufford, Sisemore, dan Blackburn berhasil mengembangkan sebuah alat ukur bernama Dimensions of Grace Scale (DGS) yang dapat mengukur pengalaman, keyakinan, dan sikap manusia terhadap kasih karunia. Penelitian ini berusaha menjelaskan tentang evaluasi struktur internal dari alat ukur DGS. Peneliti menggunakan Exploratory Analysis Factor untuk melihat pengelompokan alat ukur DGS. Selain itu, analisis reliabilitas juga dilakukan untuk melihat konsistensi internal DGS. Skala DGS diterjemahkan ke dalam Bahasa Indonesia kemudian disebarkan kepada 401 orang Kristen yang berumur 17 tahun ke atas. DGS mempunyai lima dimensi yaitu dimensi Experiencing God's Grace, Costly Grace, Grace to Self, Grace from Others, dan Grace to Others. Namun, Exploratory Analysis Factor menunjukkan bahwa pengelompokkan terbaik DGS terdapat pada enam dimensi, dimana dimensi Costly Grace terbagi menjadi dua, yaitu dimensi Grace and Responsibility dan Graceful Avoidance of Personal Legalism, sejalan dengan teori Costly Grace.
\end{abstract}

Kata Kunci: Analisis Faktor Eksplorasi; kasih karunia; kasih karunia umum; kasih karunia khusus; kasih karunia murahan; kasih karunia yang mahal 


\section{PENDAHULUAN}

Kasih karunia adalah tema utama dalam kehidupan kekristenan. Hal ini dikarenakan, kasih karunia sudah dianggap sebagai fondasi dari iman kristiani sejak dari gereja mula-mula. ${ }^{1}$ Selain itu, kasih karunia juga adalah topik yang signifikan untuk para psikolog Kristen, namun topik tersebut masih belum banyak dibahas. ${ }^{2} \mathrm{Hal}$ ini dikarenakan kasih karunia adalah realita yang hanya hidup di dalam hati orang Kristen. Walau begitu, keberadaan kasih karunia tidak dapat diabaikan karena kasih karunia masih merupakan bagian dari dimensi kehidupan manusia. ${ }^{3}$

Kasih karunia dapat didefiniskan baik secara psikologis maupun secara teologis. ${ }^{4}$ Secara psikologis, kasih karunia dapat diartikan sebagai pemberian tanpa syarat kepada seseorang yang tidak layak menerima pemberian tersebut. Dua komponen penting di dalam konsep kasih karunia adalah pemberi yang tidak ber-

\footnotetext{
${ }^{1}$ Mark R. McMinn et al., "Professional Psychology and the Doctrines of Sin and Grace: Christian Leaders' Perspectives," Professional Psychology: Research and Practice 37, no. 3 (June 2006): 295302.

2 Timothy Sisemore et al., "Grace and Christian Psychology-Part 1: Preliminary Measurement, Relationships, and Implications for Practice.," Edification: The Transdisciplinary Journal of Christian Psychology 4, no. 2 (2011): 57-63.

${ }^{3}$ Alan Tjeltveit, "Understanding Human Beings in the Light of Grace: The Possibility and Promise of Theology-Informed Psychologies," Consensus 29, no. 2 (2004): 5.
}

kewajiban untuk memberi dan penerima yang tidak layak untuk menerima. ${ }^{5}$ Elwell membagi pemberian kasih karunia menjadi dua, yaitu common grace dan special grace. ${ }^{6}$ Common grace adalah kasih karunia yang dapat dirasakan oleh semua orang tanpa terkecuali. Bentuk dari common grace dapat berupa pergantian musim, pemberian sinar matahari, hujan, dan segala jenis makanan dan pakaian. ${ }^{7} \mathrm{Hal}$ tersebut sesuai dengan Matius 5:45, "karena dengan demikianlah kamu menjadi anakanak Bapamu yang di sorga, yang menerbitkan matahari bagi orang yang jahat dan orang yang baik dan menurunkan hujan bagi orang yang benar dan orang yang tidak benar" (TB-LAI).

Kemudian, special grace adalah kasih karunia yang hanya diberikan untuk orang yang percaya Yesus sebagai Tuhan. Pemberian tersebut berupa pengampunan dosa melalui pengorbanan Yesus di kayu salib. $^{8}$ Ketika seseorang menemukan

\footnotetext{
${ }^{4}$ Rodger K. Bufford, Timothy A. Sisemore, and Amanda M. Blackburn, "Dimensions of Grace: Factor Analysis of Three Grace Scales," Psychology of Religion and Spirituality 9, no. 1 (2017): 56-69. ${ }^{5}$ Ibid.

6 Walter A. Elwell, Evangelical Dictionary of Theology (USA: Baker Publishing Group, 2001), 519-520.

${ }^{7}$ Sisemore et al., "Grace and Christian PsychologyPart 1: Preliminary Measurement, Relationships, and Implications for Practice."

${ }^{8}$ McMinn et al., "Professional Psychology and the Doctrines of Sin and Grace: Christian Leaders' Perspectives."
} 
dirinya diampuni dari segala dosanya dan terhindar dari murka Tuhan, mereka akan mengalami perubahan secara interpersonal dan intrapersonal. ${ }^{9}$ Menurut Meilander, perubahan ini terjadi karena kasih karunia juga mempunyai fungsi sebagai transforming power, yaitu untuk membimbing manusia kepada kehidupan dengan standar sorgawi. ${ }^{10}$ Salah satu rujukan dari Alkitab adalah perubahan Saulus menjadi Paulus yang dideskripsikan pada 1 Korintus 15:10, "Tetapi karena kasih karunia Allah aku adalah sebagaimana aku ada sekarang, dan kasih karunia yang dianugerahkan-Nya kepadaku tidak sia-sia. Sebaliknya, aku telah bekerja lebih keras dari pada mereka semua; tetapi bukannya aku, melainkan kasih karunia Allah yang menyertai aku" (TB-LAI). Salah satu perubahan yang terlihat nyata dalam kehidupan orang Kristen adalah perubahan sikap terhadap kehidupan dan terhadap orang disekitarnya yang biasa disebut dengan enacted grace atau juga bisa disebut dengan relational grace. $^{11}$

\footnotetext{
9 Robert A. Emmons et al., "Psychological and Theological Reflections on Grace and Its Relevance for Science and Practice.," Psychology of Religion and Spirituality 9, no. 3 (August 1, 2017): 276-284, accessed August 5, 2020, /record/2017-35611-005.

10 Tjeltveit, "Understanding Human Beings in the Light of Grace: The Possibility and Promise of Theology-Informed Psychologies."

${ }^{11}$ James N. Sells and Mark A.Yarhouse, Counseling Couples in Conflict (USA: Inter-Varsity Press, 2011), 125.
}

Pada beberapa tradisi kekristenan ada pengertian yang berbeda tentang kasih karunia. Ada pandangan yang mempercayai bahwa kasih karunia mengampuni dosa manusia, sehingga manusia dapat melakukan apa yang ingin mereka lakukan dalam kehidupan. Pandangan biasa disebut dengan cheap grace. ${ }^{12}$ Cheap grace mendeskripsikan bahwa keselamatan didapatkan melalui pertobatan manusia. Hal tersebut berbeda dengan keyakinan pada umumnya dari umat Kristiani, bahwa keselamatan manusia hanya diberikan oleh Tuhan melalui anakNya, Yesus Kristus yang mati di kayu salib. Pertobatan dan ketaatan iman adalah hasil dari keselamatan yang diberikan, bukan syarat atas keselamatan manusia dari dosa. ${ }^{13}$ Paham yang bertolak belakang dari cheap grace adalah costly grace. Costly grace adalah pandangan bahwa kasih karunia memanggil kita untuk mengikut Yesus. ${ }^{14}$ Panggilan ini adalah hasil dari keselamatan dan pengampunan yang diberikan Tuhan atas jiwa manusia yang hancur dan hati manusia yang jahat. ${ }^{15}$ Piper

\footnotetext{
12 Dietrich Bonhoeffer, The Cost of Discipleship (London: SCM Press Ltd, 2015), 43-44.

${ }^{13}$ T. F. Torrance, "Cheap and Costly Grace," Baptist Quarterly 22, no. 6 (January 1968): 290-312, accessed August 5, 2020, https:// www.tandfonline.com/doi/abs/10.1080/0005576X. 1968.11751246.

${ }^{14}$ Bonhoeffer, The Cost of Discipleship, 45.

${ }^{15}$ Ibid.
} 
mengatakan bahwa ketaatan adalah bukti dari pembaharuan batin manusia oleh Tuhan, sesuai dengan apa yang dikatakan Roma 6:17, “Tetapi syukurlah kepada Allah! Dahulu memang kamu hamba dosa, tetapi sekarang kamu dengan segenap hati telah mentaati pengajaran yang telah diteruskan kepadamu" (TB-LAI). ${ }^{16}$

Seorang pendeta dari salah satu denominasi gereja di Surabaya dengan inisial JB menjelaskan tentang pentingnya kasih karunia di dalam gereja. Pendeta JB mengatakan bahwa hampir setiap minggu topik yang diajarkan adalah kasih karunia. Namun, tidak ada alat ukur yang dapat secara empiris mengukur pengertian, pengalaman, dan sikap seseorang terhadap kasih karunia. Salah satu metode yang digunakan oleh kebanyakan gereja adalah dengan mengobservasi perilaku jemaat. Meskipun demikian, pendeta JB mengatakan bahwa pengukuran tersebut masih tergolong kurang valid. Seorang jemaat dengan inisial KA di salah satu denominasi gereja di Surabaya mempunyai sebuah pengalaman yang mendukung pernyataan pendeta JB. KA mengaku bahwa dia masih tidak mengerti tentang kasih karunia setelah

\footnotetext{
16 John Piper, Five Points: Towards a Deeper Experience of God's Grace (Scotland: Christian Focus Publication, 2013), 67.

17 Tjeltveit, "Understanding Human Beings in the Light of Grace: The Possibility and Promise of Theology-Informed Psychologies."
}

dia mengikuti kelas yang khusus menjelaskan kasih karunia di gerejanya. KA mengatakan bahwa dampak kasih karunia di kehidupannya setelah mengikuti kelas masih sangat kecil. Fenomena ini menekankan pentingnya melakukan validasi alat ukur kasih karunia sebagai evaluasi jemaat di dalam gereja.

Kasih karunia adalah sebuah realita yang hanya hidup di dalam hati orang Kristen, sehingga kasih karunia tidak dapat diukur dan dimanipulasi. Namun, Tjeltveit mengatakan bahwa pengukuran dapat dilakukan jika kontruk yang diukur adalah pengaruh kasih karunia terhadap kehidupan manusia yang dapat berupa pengalaman, sikap, dan juga pengertian.${ }^{17}$ Salah satu alat ukur yang secara lengkap megukur pengalaman, keyakinan, dan sikap seseorang terhadap kasih karunia adalah alat ukur Dimensions of Grace Scale (DGS). ${ }^{18}$ DGS adalah alat ukur yang dikembangkan oleh Bufford, Sisemore, dan Blackburn pada tahun 2017, yang terbentuk dari tiga alat ukur kasih karunia yang lain, yaitu Grace Scale (GS) yang dikembangkan oleh Spradlin pada tahun 2002, Richmont Grace Scale (RGS) yang dibuat oleh Watson,

\footnotetext{
18 Emmons et al., "Psychological and Theological Reflections on Grace and Its Relevance for Science and Practice."
} 
Chen, dan Sisemore pada tahun 2011, dan The Amazing Grace Scale (TAGS) yang dikembangkan oleh Basset dan Robert Wesleyan Psychology Research Group pada tahun $2013 .^{19}$

Masing-masing alat ukur, GS, RGS, dan TAGS, dibentuk dengan konsep karunia yang berbeda-beda. GS mengukur pengalaman dan ekspresi kasih karunia dalam cakupan common grace dan special grace. RGS mengukur pengalaman dan perwujudan kasih karunia, khususnya special grace. Sedangkan, TAGS mengukur pengalaman dan kesadaran manusia terhadap special grace. ${ }^{20}$ Dengan demikian, DGS adalah alat ukur yang mengukur konsep kasih karunia yang lebih luas dibandingkan dengan alat ukur GS, RGS, dan TAGS secara individual.

Tujuan dari penelitian ini adalah untuk mengevaluasi struktur internal dari alat ukur DGS menggunakan metode exploratory factor analysis (EFA) dan metode reliabilitas. Penelitian sebelumnya yang dilakukan oleh Bufford, Sisemore, dan Blackburn pada tahun 2017 menunjukkan bahwa DGS mempunyai 36 butir yang

\footnotetext{
${ }^{19}$ Bufford, Sisemore, and Blackburn, "Dimensions of Grace: Factor Analysis of Three Grace Scales."

${ }^{20}$ Ibid.

${ }^{21}$ Ibid.

${ }^{22}$ Sonny Eli Zaluchu, "Strategi Penelitian Kualitatif Dan Kuantitatif Di Dalam Penelitian Agama," Evangelikal: Jurnal Teologi Injili dan Pembinaan
}

terbagi menjadi lima dimensi yaitu, Experiencing God's Grace (EG), Costly Grace (CG), Grace to Self (GTS), Grace from Others (GFO), dan Grace to Others (GTO). ${ }^{21}$

\section{METODE PENELITIAN}

Metode yang digunakan pada penelitian ini adalah metode kuantitatif. Metode ini digunakan untuk membuktikan kebenaran dari sebuah fenomena dalam bentuk variabel-varabel dari teori yang diyakini selama ini. $^{22}$ Peneliti menggunakan tipe exploratory research, dimana peneliti menggali suatu masalah atau konsep yang menjadi dasar dari metode penelitian konklusif. ${ }^{23}$ Peneliti ingin melihat apakah alat ukur DGS yang mengukur mengenai pengalaman, sikap, dan pengetahuan manusia terhadap kasih karunia memiliki sumber bukti struktur internal seperti apa yang dilakukan oleh Bufford, Sisemore, dan Blackburn.

Sampel subjek pada penelitian ini adalah 401 orang Kristen yang berumur di atas 17 tahun. Mayoritas subjek pada penelitian ini berjenis kelamin perempuan, yaitu sebanyak 238 subjek. Sedangkan,

Warga Jemaat 4, no. 1 (2020): 28-38, accessed April 4, 2020, https://journal.sttsimpson.ac.id/ index.php/EJTI/article/view/167.

23 Kultar Singh, Quantitative Social Research Methods (New Delhi: Sage Publications Pvt Ltd, 2007), 63-64 
terdapat 156 subjek berjenis kelamin lakilaki dan 7 subjek yang memilih untuk tidak menjawab jenis kelamin. Sebanyak $70 \%$ Partisipan pada penelitian ini berumur dibawah 25 tahun. Kemudian, 30.2\% berasal dari denominasi Gereja Bethel Indonesia (GBI). Peneliti mendapatkan subjek penelitian dengan menggunakan accidental sampling, yang artinya memilih subjek yang mudah dihubungi, praktis, dan tersedia. Peneliti menerjemahkan DGS ke dalam bahasa Indonesia kemudian disebarkan melalui survei online. Penyebaran survei online dilakukan melalui sosial media seperti Line, Whatsapp, dan Instagram. Partisipan dari penelitian ini diwajibkan mengisi semua butir pada kuesioner online untuk mencegah adanya data yang hilang.

Alat ukur DGS mengukur pengalaman, keyakinan, dan sikap terhadap kasih karunia. ${ }^{24}$ DGS mempunyai 36 butir yang mengelompok menjadi lima faktor. Akan tetapi, peneliti memutuskan untuk menambah 3 butir. Berikut adalah tabel yang berisikan terjemahan butir tambahan alat ukur DGS.
Tabel 1. Terjemahan butir tambahan DGS

\begin{tabular}{|c|c|c|}
\hline Original items & Translated items & Items \\
\hline \multirow{2}{*}{$\begin{array}{l}\text { My behavior } \\
\text { does not matter } \\
\text { since I am } \\
\text { forgiven. }\end{array}$} & $\begin{array}{l}\text { Apa yang saya lakukan } \\
\text { tidaklah penting karena } \\
\text { saya sudah diampuni. }\end{array}$ & 9 \\
\hline & $\begin{array}{l}\text { Saya dapat melakukan apa } \\
\text { saja karena telah diampuni. }\end{array}$ & $9 \mathrm{~N}$ \\
\hline \multirow{2}{*}{$\begin{array}{l}\text { I seldom feel } \\
\text { shame. }\end{array}$} & $\begin{array}{c}\text { Saya jarang merasa malu } \\
\text { karena diri saya. }\end{array}$ & 18 \\
\hline & $\begin{array}{c}\text { Saya jarang merasa malu } \\
\text { terhadap diri saya. }\end{array}$ & $18 \mathrm{~N}$ \\
\hline $\begin{array}{l}\text { My Dad } \\
\text { seldom said } \\
\text { thank you. }\end{array}$ & $\begin{array}{c}\text { Ayah saya jarang } \\
\text { mengucapkan terima kasih. }\end{array}$ & 27 \\
\hline $\begin{array}{l}\text { My Mom } \\
\text { seldom said } \\
\text { thank you. }\end{array}$ & $\begin{array}{c}\text { Ibu saya jarang } \\
\text { mengucapkan terima kasih. }\end{array}$ & $27 \mathrm{~N}$ \\
\hline
\end{tabular}

Dapat dilihat dari tabel 1 butir-butir baru diberi nama $9 \mathrm{~N}, 18 \mathrm{~N}$, dan $27 \mathrm{~N}$. Butir 9N dan $18 \mathrm{~N}$ dibuat sebagai alternatif terjemahan dengan butir aslinya yaitu butir 9 dan 18. Peneliti membandingkan butir 9N dan $18 \mathrm{~N}$ dengan butir 9 dan 18 untuk menentukan butir mana yang memiliki terjemahan yang terbaik. Butir $27 \mathrm{~N}$ ditambahkan sebagai tanggapan terhadap butir 27. Butir 27 hanya menyebutkan terkait Ayah, sehingga peneliti menambahkan butir $27 \mathrm{~N}$ yang menyebutkan terkait Ibu. Total butir yang disebarkan melalui kuesioner online adalah 39 butir. Tabel 2 menunjukkan spesifikasi dari DGS versi Bahasa Indonesia.

\footnotetext{
${ }^{24}$ Emmons et al., "Psychological and Theological Reflections on Grace and Its Relevance for Science and Practice."
} 
Tabel 2. Spesifikasi DGS versi Bahasa Indonesia

\begin{tabular}{|c|c|c|c|}
\hline \multirow[t]{2}{*}{ Dimensi } & \multicolumn{2}{|c|}{ Butir } & \multirow{2}{*}{$\begin{array}{c}\text { Jumla } \\
\text { h } \\
\text { Butir }\end{array}$} \\
\hline & $\begin{array}{c}\text { Favorabl } \\
e\end{array}$ & $\begin{array}{c}\text { Unfavorabl } \\
e\end{array}$ & \\
\hline $\begin{array}{c}\text { Experiencin } \\
\text { g God's } \\
\text { Grace }\end{array}$ & $\begin{array}{l}1,2,3,4 \\
5,6,7,8\end{array}$ & - & 8 \\
\hline $\begin{array}{l}\text { Costly } \\
\text { Grace }\end{array}$ & - & $\begin{array}{c}9,9 \mathrm{~N}, 10 \\
11,12,13 \\
14,15\end{array}$ & 8 \\
\hline $\begin{array}{l}\text { Grace to } \\
\text { Self }\end{array}$ & $\begin{array}{c}18,18 \mathrm{~N} \\
19,20 \\
21\end{array}$ & $16,17,22$ & 8 \\
\hline $\begin{array}{c}\text { Grace from } \\
\text { Others }\end{array}$ & & $\begin{array}{c}23,24,25 \\
26,27 \\
27 N, 28,29\end{array}$ & 8 \\
\hline $\begin{array}{c}\text { Grace to } \\
\text { Others }\end{array}$ & - & $\begin{array}{c}30,31,32 \\
33,34,35 \\
36\end{array}$ & 7 \\
\hline & Total & & 39 \\
\hline
\end{tabular}

Penelitian ini mengevaluasi struktur internal dari DGS menggunakan dua metode, yaitu analisis faktor dan analisis reliabilitas. Metode faktor analisis dan reliabilitas adalah metode yang digunakan untuk mengetahui struktur internal sebuah alat ukur. ${ }^{25}$ Faktor analisis menjelaskan tentang analisis prosedur matematika yang kompleks mengenai hubungan antar variabel-variabel terhadap kelompok variabel. ${ }^{26}$ Metode ini dipengaruhi oleh muatan faktor

25 Lina Natalya and Cynthia Vivian Purwanto, "Exploratory and Confirmatory Factor Analysis of the Academic Motivation Scale (AMS)-Bahasa Indonesia," Makara Human Behavior Studies in Asia 22, no. 1 (July 27, 2018): 29.

${ }^{26}$ Saiffudin Azwar, Reliabilitas Dan Validitas, 3rd ed. (Yogyakarta: Pustaka Pelajar, 2012).

${ }^{27}$ Lina Natalya, "Struktur Internal," in Teori Dan Praktik Cara Asyik Belajar Pengukuran Psikologis (Surabaya: Centre of Lifelong Learning, 2016), 63.

${ }^{28}$ Ibid.

${ }^{29}$ Ibid. yang didefinisikan sebagai besaran varian yang dipunyai sebuah butir terhadap kontruk pada suatu alat ukur. ${ }^{27}$ Sebuah validitas faktor dapat dikatakan baik jika muatan faktor dari semua variabel tinggi pada faktor yang sedang dievaluasi, dan rendah pada faktor yang lainnya. ${ }^{28}$

Faktor analisis mempunya tiga macam metode yaitu, confirmatory factor analysis (CFA), exploratory factor analysis (EFA), dan Multitrait-Multimethod Matrix (MTMM). ${ }^{29}$ Penelitian ini akan menggunakan metode EFA. Menurut Child sebagai-mana dikutip oleh Lina dan Cynthia, metode EFA bertujuan untuk mengukur pengelompokkan butir berdasarkan data yang sudah didapatkan. ${ }^{30}$ Menurut Singgih Santoso, sebelum melakukan proses EFA, terdapat beberapa hal yang harus dipenuhi. $^{31}$ Syarat pertama adalah nilai Kaiser-Meyer-Olkin (KMO) harus sama atau melebihi $0.5(\mathrm{KMO} \geq 0.5)$. Nilai $\mathrm{KMO}$ yang sama atau melebihi 0.5 mempunyai arti bahwa terdapat cukup partisipan di

30 Natalya and Purwanto, "Exploratory and Confirmatory Factor Analysis of the Academic Motivation Scale (AMS)-Bahasa Indonesia."

31 Meinarini Catur Utami, "Analisis Faktor-faktor yang Mempengaruhi Dosen dalam Melanjutkan S3 dengan Metode Principal Component Analysis (Studi Kasus: Program Studi SI/TI FST UIN)," Jurnal Sistem Informasi 6, no. 1 (April 19, 2013): 17, accessed August 6, 2020, http:// journal.uinjkt.ac.id/index.php/sisteminformasi/articl e/view/313. 
dalam penelitian ini sehingga analisis dapat dilanjutkan. ${ }^{32}$ Syarat kedua yang harus dipenuhi adalah nilai dari Significance Bartlett's Test of Sphericity harus sama atau dibawah 0.05 (sig $\leq 0.05)$. Nilai dari Significance Bartlett's Test of Sphericity menunjukkan penyebaran data. Jika memenuhi syarat, maka data tersebar secara merata, sehingga hasil dari analisis faktor tidak terjadi secara kebetulan. ${ }^{33}$ Syarat dari validitas yang baik adalah jika sebuah butir mempunyai muatan faktor yang sama atau lebih besar dari $0.4^{34}$ sesuai dengan dimensi awal tanpa adanya zero loading atau cross loading pada faktor yang lain. ${ }^{35}$

Selain menggunakan EFA, analisis reliabilitas juga akan digunakan pada penelitian ini. Reliabilitas berbicara tentang sejauh sebuah pengukuran dapat dipercaya. ${ }^{36}$ Jika dilakukan beberapa kali pelaksanaan pada aspek yang sama terhadap kelompok subjek yang sama menghasilkan hasil yang relatif sama, maka sebuah

\footnotetext{
32 WOM and Cynthia Vivian. Purwanto, "Panduan Analisis Data," in Teori Dan Praktik Cara Asyik Belajar Pengukuran Psikologis (Surabaya: Centre of Lifelong Learning, 2016), 93.

33 Sigmund Tobias and James E. Carlson, "Brief Report: Bartlett's Test of Sphericity and Chance Findings in Factor Analysis," Multivariate Behavioral Research 4, no. 3 (July 1, 1969): 375377, accessed August 6, 2020, https:// www.tandfonline.com/doi/abs/10.1207/s15327906 mbr0403_8.

34 Justyna Wiktorowicz, "Exploratory Factor Analysis in the Measurement of the Competencies of Older People," Ekonometria, no. 54 (2016): 48-60.
}

pengukuran dapat dipercaya. ${ }^{37}$ Metode reliabilitas yang digunakan pada penelitian ini menggunakan koefisian alpha, yang mengukur konsistensi antar-item dalam tes. ${ }^{38}$ Menurut Hair dan Krey suatu butir dapat dikatakan reliabel jika nilai dari koefisien alpha cronbach mencapai angka 0.7 atau lebih dan memiliki corrected-item total correlation (CITC) sama atau lebih dari 0.3. ${ }^{39}$ Semua kalkulasi pada penelitian ini akan dilakukan dengan menggunakan software SPSS versi 24.

\section{HASIL DAN PEMBAHASAN}

\section{Analisis Faktor}

Hasil analisis dari SPSS versi 24 menunjukkan bahwa data yang diambil memiliki nilai KMO yang mencapai 0.829 dan nilai signifikansi Bartlett pada 0.000 . Kedua nilai dari KMO dan signifikansi Bartlett memenuhi syarat, sehingga analisis dapat dilanjutkan ke tahap yang berikutnya.

35 Natalya and Purwanto, "Exploratory and Confirmatory Factor Analysis of the Academic Motivation Scale (AMS)-Bahasa Indonesia."

${ }^{36}$ Azwar, Reliabilitas Dan Validitas.

37 Ibid.

${ }^{38}$ Ibid.

39 Cynthia Vivian Purwanto and Lina Natalya, "Tomorrow Will Always Come, I Am a Last-Minute Person: Validation of the Active Procrastination Scale-Bahasa Indonesia," Makara Human Behavior Studies in Asia 23, no. 1 (July 31, 2019): 46. 
Tabel 3. Usulan factor

\begin{tabular}{|c|c|c|c|c|c|c|}
\hline \multirow[b]{2}{*}{$\begin{array}{c}\mathrm{N} \\
\mathrm{O}\end{array}$} & \multirow[b]{2}{*}{$\begin{array}{c}\text { Kriteri } \\
\text { on }\end{array}$} & \multirow[b]{2}{*}{$\begin{array}{c}\text { Usula } \\
n \\
\text { faktor }\end{array}$} & \multicolumn{4}{|c|}{ Jumlah Butir } \\
\hline & & & $\begin{array}{l}\text { Singl } \\
e \\
\text { Load } \\
\text { ing }\end{array}$ & $\begin{array}{c}\text { Single } \\
\text { loading } \\
\text { pada } \\
\text { faktor } \\
\text { lain } \\
\end{array}$ & $\begin{array}{c}\text { Cro } \\
\text { ss } \\
\text { Loa } \\
\text { ding }\end{array}$ & $\begin{array}{c}\text { Zero } \\
\text { Loa } \\
\text { ding }\end{array}$ \\
\hline 1 & $\begin{array}{c}\text { A } \\
\text { Priori }\end{array}$ & 5 & 31 & 5 & 1 & 2 \\
\hline 2 & $\begin{array}{c}\text { Percen } \\
\text { tage of } \\
\text { varian } \\
\text { ce } \\
\text { explain } \\
\text { ed }\end{array}$ & 6 & 34 & 3 & 0 & 2 \\
\hline 3 & $\begin{array}{c}\text { Scree } \\
\text { test }\end{array}$ & 9 & 37 & 0 & 1 & 1 \\
\hline
\end{tabular}

\begin{tabular}{|c|c|c|c|c|c|c|}
\hline \multirow[b]{2}{*}{$\begin{array}{c}\mathrm{N} \\
\mathrm{O}\end{array}$} & \multirow[b]{2}{*}{$\begin{array}{c}\text { Kriteri } \\
\text { on }\end{array}$} & \multirow[b]{2}{*}{$\begin{array}{c}\text { Usula } \\
n \\
\text { faktor }\end{array}$} & \multicolumn{4}{|c|}{ Jumlah Butir } \\
\hline & & & $\begin{array}{c}\text { Singl } \\
e \\
\text { Load } \\
\text { ing }\end{array}$ & $\begin{array}{c}\text { Single } \\
\text { loading } \\
\text { pada } \\
\text { faktor } \\
\text { lain }\end{array}$ & $\begin{array}{c}\text { Cro } \\
\text { ss } \\
\text { Loa } \\
\text { ding }\end{array}$ & $\begin{array}{c}\text { Zero } \\
\text { Loa } \\
\text { ding }\end{array}$ \\
\hline 4 & $\begin{array}{c}\text { Latent } \\
\text { Root }\end{array}$ & 9 & 37 & 0 & 1 & 1 \\
\hline
\end{tabular}

Pada tabel 3 dapat dilihat beberapa usulan faktor DGS berdasarkan a priori, percentage of variance explained criterion, scree test criterion, dan latent root criterion. 
Tabel 4. Pengelompokan butir berdasarkan Sembilan faktor

\begin{tabular}{|c|c|c|c|c|c|c|c|c|c|c|c|}
\hline \multicolumn{3}{|c|}{ No } & \multicolumn{9}{|c|}{ Sesudah exploratory analysis factor } \\
\hline & & & EG & GTO & GFO & GAPL & GR & GTS & GTS & GFO & GFO \\
\hline & & & & & 1 & & & 1 & 2 & 2 & 3 \\
\hline \multirow{39}{*}{ 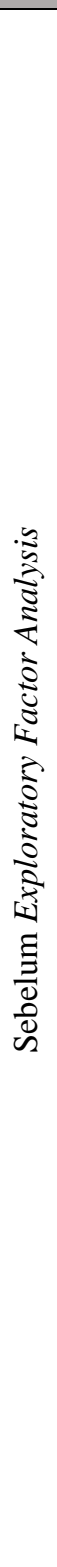 } & EG & 1 & 0.753 & & & & & & & & \\
\hline & & 2 & 0.756 & & & & & & & & \\
\hline & & 3 & 0.713 & & & & & & & & \\
\hline & & 4 & 0.599 & & & & & & & & \\
\hline & & 5 & 0.789 & & & & & & & & \\
\hline & & 6 & 0.586 & & & & & & & & \\
\hline & & 7 & 0.440 & & & & & & & & \\
\hline & & 8 & 0.652 & & & & & & & & \\
\hline & $\mathrm{CG}$ & 9 & & & & & 0.779 & & & & \\
\hline & & $9 \mathrm{~N}$ & & & & & 0.815 & & & & \\
\hline & & 10 & & & & & 0.677 & & & & \\
\hline & & 11 & & & & & 0.657 & & & & \\
\hline & & 12 & & & & 0.499 & & & & & \\
\hline & & 13 & & & & 0.837 & & & & & \\
\hline & & 14 & & & & 0.836 & & & & & \\
\hline & & 15 & & & & 0.772 & & & & & \\
\hline & GTS & 16 & & & & & & & 0.764 & & \\
\hline & & 17 & & & & & & & 0.695 & & \\
\hline & & 18 & & & & & & 0.768 & & & \\
\hline & & $18 \mathrm{~N}$ & & & & & & 0.796 & & & \\
\hline & & 19 & & & & & & 0.613 & & & \\
\hline & & 20 & & & & & & 0.613 & & & \\
\hline & & 21 & & & & & & 0.675 & & & \\
\hline & & 22 & & & & & & & 0.557 & & \\
\hline & GFO & 23 & & & 0.802 & & & & & & \\
\hline & & 24 & & & 0.812 & & & & & & \\
\hline & & 25 & & & 0.798 & & & & & & \\
\hline & & 26 & & & 0.676 & & & & & & \\
\hline & & 27 & & & & & & & & 0.833 & \\
\hline & & $27 \mathrm{~N}$ & & & & & & & & 0.790 & \\
\hline & & 28 & & & & & & & & & 0.808 \\
\hline & & 29 & & & 0.439 & & & & & & \\
\hline & GTO & 30 & & 0.767 & & & & & & & \\
\hline & & 31 & & 0.612 & & & & & & & \\
\hline & & 32 & & 0.722 & & & & & & & \\
\hline & & 33 & & 0.722 & & & & & & & \\
\hline & & 34 & & 0.652 & & & & & & & \\
\hline & & 35 & & 0.654 & & & & & & & \\
\hline & & 36 & & & & 0.401 & & & & & \\
\hline
\end{tabular}

Terlihat bahwa pada tabel 3, usulan yang mempunyai penyimpangan paling sedikit dan single loading paling banyak adalah usulan 9 faktor. Namun pada 9 faktor, terdapat beberapa dimensi yang hanya memiliki kurang dari tiga butir, yaitu pada dimensi GFO 2 dan GFO 3 seperti yang tertera pada tabel 4. Dimensi yang memiliki kurang dari tiga butir di dalamnya bukanlah dimensi yang baik. Maka dari itu, peneliti memutuskan untuk tidak menggunakan usulan 9 faktor, melainkan usulan 6 faktor. 
Tabel 5. Pengelompokkan butir berdasarkan enam faktor

\begin{tabular}{|c|c|c|c|c|c|c|c|c|}
\hline & & No & & Sesu & Explorat & Factor $A$ & & \\
\hline & & & GTO & EG & GFO & GR & GAPL & GTS \\
\hline & EG & 1 & & 0.751 & & & & \\
\hline & & 2 & & 0.751 & & & & \\
\hline & & 3 & & 0.713 & & & & \\
\hline & & 4 & & 0.619 & & & & \\
\hline & & 5 & & 0.777 & & & & \\
\hline & & 6 & & 0.574 & & & & \\
\hline & & 7 & & 0.468 & & & & \\
\hline & & 8 & & 0.640 & & & & \\
\hline & $\mathrm{CG}$ & 9 & & & & 0.739 & & \\
\hline & & $9 \mathrm{~N}$ & & & & 0.777 & & \\
\hline & & 10 & & & & 0.732 & & \\
\hline & & 11 & & & & 0.712 & & \\
\hline & & 12 & & & & & 0.485 & \\
\hline & & 13 & & & & & 0.823 & \\
\hline$\stackrel{5}{3}$ & & 14 & & & & & 0.827 & \\
\hline$\stackrel{1}{\Sigma}$ & & 15 & & & & & 0.760 & \\
\hline$\grave{s}$ & GTS & 16 & 0.476 & & & & & \\
\hline క్ర & & 17 & 0.489 & & & & & \\
\hline 2 & & 18 & & & & & & 0.690 \\
\hline 5 & & $18 \mathrm{~N}$ & & & & & & 0.772 \\
\hline$\frac{2}{2}$ & & 19 & & & & & & 0.499 \\
\hline$\overline{\widetilde{T}}$ & & 20 & & & & & & 0.649 \\
\hline Is & & 21 & & & & & & 0.700 \\
\hline$\Xi$ & & 22 & & & & & & \\
\hline$\stackrel{0}{0}$ & GFO & 23 & & & 0.659 & & & \\
\hline & & 24 & & & 0.750 & & & \\
\hline & & 25 & & & 0.752 & & & \\
\hline & & 26 & & & 0.727 & & & \\
\hline & & 27 & & & 0.679 & & & \\
\hline & & $27 N$ & & & 0.706 & & & \\
\hline & & 28 & & & & & & \\
\hline & & 29 & & & 0.579 & & & \\
\hline & GTO & 30 & 0.669 & & & & & \\
\hline & & 31 & 0.788 & & & & & \\
\hline & & 32 & 0.622 & & & & & \\
\hline & & 33 & 0.680 & & & & & \\
\hline & & 34 & 0.664 & & & & & \\
\hline & & 35 & 0.661 & & & & & \\
\hline & & 36 & & & & & 0.411 & \\
\hline
\end{tabular}

Peneliti memilih menggunakan usulan 6 faktor karena memiliki penyimpangan lebih sedikit dibandingkan dengan 5 faktor. Dapat dilihat pada tabel 5 bahwa hasil EFA dari pengelompokkan 6 faktor menunjukkan bahwa dimensi costly grace 
memecah menjadi dua dimensi yaitu dimensi Grace and Responsibility (GR) dan Graceful Avoidance of Personal Legalism (GAPL). Selain itu, terdapat beberapa butir yang single loading pada faktor lain yaitu butir 16, 17, dan 36. Kemudian terlihat butir yang zero loading adalah butir nomor 22 dan 28. Peneliti memertahankan butir 16 pada dimensi awalnya dan menggugurkan butir yang lainnya. Tabel 6 menunjukkan menunjukkan perlakuan untuk butir-butir tersebut secara spesifik.

Tabel 6. Perlakuan butir analisis faktor

\begin{tabular}{|c|c|c|c|c|}
\hline $\begin{array}{l}\text { Nom } \\
\text { or } \\
\text { butir }\end{array}$ & $\begin{array}{l}\text { Kondi } \\
\text { si } \\
\text { butir }\end{array}$ & $\begin{array}{l}\text { Facto } \\
\mathrm{r} \\
\text { loadin } \\
\mathrm{g} \\
\text { (FL) } \\
\text { dimen } \\
\text { si } \\
\text { awal }\end{array}$ & $\begin{array}{l}\text { Kesesua } \\
\text { ian } \\
\text { definisi }\end{array}$ & Perlakuan \\
\hline 16 & $\begin{array}{l}\text { FL di } \\
\text { faktor } \\
\text { GTO }\end{array}$ & $\begin{array}{l}- \\
0.304\end{array}$ & $\begin{array}{l}\text { Sesuai } \\
\text { dengan } \\
\text { dimensi } \\
\text { awal }\end{array}$ & \begin{tabular}{l}
\multicolumn{2}{c}{ Dipertahan } \\
kan di \\
dimensi \\
awal
\end{tabular} \\
\hline 17 & $\begin{array}{l}\text { FL di } \\
\text { faktor } \\
\text { GTO }\end{array}$ & - & $\begin{array}{l}\text { Sesuai } \\
\text { dengan } \\
\text { dimensi } \\
\text { awal }\end{array}$ & $\begin{array}{l}\text { Digugurka } \\
\mathrm{n}\end{array}$ \\
\hline 22 & $\begin{array}{l}\text { Zero } \\
\text { loadi } \\
n g\end{array}$ & $\begin{array}{l}- \\
0.124\end{array}$ & $\begin{array}{l}\text { Sesuai } \\
\text { dengan } \\
\text { dimensi } \\
\text { awal }\end{array}$ & $\begin{array}{l}\text { Digugurka } \\
\mathrm{n}\end{array}$ \\
\hline 28 & $\begin{array}{l}\text { Zero } \\
\text { loadi } \\
n g\end{array}$ & $-\overline{0.042}$ & $\begin{array}{l}\text { Sesuai } \\
\text { dengan } \\
\text { dimensi } \\
\text { awal }\end{array}$ & $\begin{array}{l}\text { Digugurka } \\
\mathrm{n}\end{array}$ \\
\hline 36 & $\begin{array}{l}\text { FL di } \\
\text { faktor } \\
\text { GAP } \\
\text { L }\end{array}$ & $\begin{array}{l}- \\
0.225\end{array}$ & $\begin{array}{l}\text { Sesuai } \\
\text { dengan } \\
\text { dimensi } \\
\text { awal }\end{array}$ & $\begin{array}{l}\text { Digugurka } \\
\mathrm{n}\end{array}$ \\
\hline
\end{tabular}

\section{Analisis Reliabilitas}

Kemudian peneliti melakukan analisis reliabilitas pada usulan 9 faktor dan usulan 6 faktor. Tabel 7 menunjukkan hasil reliabilitas DGS dengan pengelompokkan 9 faktor.

Tabel 7. Reliabilitas blueprint usulan 9 faktor

\begin{tabular}{|c|c|c|c|c|}
\hline \multirow[b]{2}{*}{ Nomor } & \multirow[b]{2}{*}{ Dimensi } & \multicolumn{3}{|c|}{ Hasil reliabilitas terbaik } \\
\hline & & $\begin{array}{c}\text { Alpha } \\
\text { Cronb } \\
\text { ach }\end{array}$ & $\begin{array}{c}\text { Rentang } \\
\text { CITC }\end{array}$ & $\begin{array}{c}\text { Jumlah } \\
\text { Butir }\end{array}$ \\
\hline 1 & $\begin{array}{l}\text { Experiencing } \\
\text { God's Grace }\end{array}$ & 0.829 & $\begin{array}{c}0.377- \\
0.717\end{array}$ & 8 \\
\hline 2 & Grace to Others & 0.825 & $\begin{array}{c}0.457- \\
0.699\end{array}$ & 6 \\
\hline 3 & $\begin{array}{c}\text { Grace from } \\
\text { Others } 1\end{array}$ & 0.819 & $\begin{array}{c}0.458- \\
0.710\end{array}$ & 5 \\
\hline 4 & $\begin{array}{c}\text { Grace Avoidance } \\
\text { of Personal } \\
\text { Legalism }\end{array}$ & 0.827 & $\begin{array}{c}0.467- \\
0.767\end{array}$ & 4 \\
\hline 5 & $\begin{array}{c}\text { Grace and } \\
\text { Responsibility }\end{array}$ & 0.726 & $\begin{array}{l}0.474- \\
0.637\end{array}$ & 3 \\
\hline 6 & Grace to Self 1 & 0.740 & $\begin{array}{l}0.375- \\
0.585\end{array}$ & 5 \\
\hline 7 & Grace to Self 2 & 0.716 & $\begin{array}{c}0.448- \\
0.569\end{array}$ & 3 \\
\hline 8 & $\begin{array}{c}\text { Grace from } \\
\text { Others } 2\end{array}$ & - & - & 2 \\
\hline 9 & $\begin{array}{c}\text { Grace from } \\
\text { Others } 3\end{array}$ & - & - & 1 \\
\hline
\end{tabular}

Semua dimensi pada tabel 7 memiliki alpha cronbach di atas 0.7 kecuali pada dimensi grace from others 2 (GFO2) dan grace from others 3 (GFO 3). Dimensi GFO 2 dan GFO 3 tidak menunjukkan angka alpha cronbach karena dimensidimensi tersebut hanya mempunyai jumlah butir di bawah 3 . Hal ini memperkuat argumen peneliti untuk tidak menggunakan 
usulan 9 faktor. Reliabilitas blueprint usulan 6 faktor ditunjukkan melalui tabel 8 .

Tabel 8. Reliabilitas blueprint usulan 6 faktor

\begin{tabular}{|c|c|c|c|c|}
\hline \multirow[b]{2}{*}{ Nomor } & \multirow[b]{2}{*}{ Dimensi } & \multicolumn{3}{|c|}{ Hasil reliabilitas terbaik } \\
\hline & & $\begin{array}{c}\text { Alpha } \\
\text { Cronbach }\end{array}$ & $\begin{array}{l}\text { Rentan } \\
\text { g CITC }\end{array}$ & $\begin{array}{c}\text { Jumlah } \\
\text { Butir }\end{array}$ \\
\hline 1 & $\begin{array}{c}\text { Grace to } \\
\text { Others }\end{array}$ & 0.825 & $\begin{array}{l}0.457- \\
0.699\end{array}$ & 6 \\
\hline 2 & $\begin{array}{l}\text { Experiencing } \\
\text { God's Grace }\end{array}$ & 0.829 & $\begin{array}{l}0.377- \\
0.717\end{array}$ & 8 \\
\hline 3 & $\begin{array}{c}\text { Grace from } \\
\text { Others }\end{array}$ & 0.832 & $\begin{array}{c}0.493- \\
0.672\end{array}$ & 7 \\
\hline 4 & $\begin{array}{c}\text { Grace and } \\
\text { Responsibility }\end{array}$ & 0.726 & $\begin{array}{c}0.474- \\
0.637\end{array}$ & 3 \\
\hline 5 & $\begin{array}{c}\text { Graceful } \\
\text { Avoidance of } \\
\text { Personal } \\
\text { Legalism }\end{array}$ & 0.827 & $\begin{array}{c}0.467- \\
0.767\end{array}$ & 4 \\
\hline 6 & Grace to Self & 0.701 & $\begin{array}{c}0.378- \\
0.573\end{array}$ & 4 \\
\hline
\end{tabular}

Dapat dilihat dari tabel 8 bahwa semua dimensi dari DGS usulan 8 faktor mempunyai alpha cronbach di atas 0.7 dan CITC di atas 0.3. Maka dari itu, dapat dikatakan bahwa semua dimensi pada alat ukur DGS memiliki konsistensi internal yang baik. Untuk mencapai reliabilitas tersebut, terdapat beberapa perlakuan butir yang ditunjukkan pada tabel 9.

Tabel 9. Perlakuan butir analisis reliabilitas hasil blueprint analisis faktor

\begin{tabular}{llll}
\hline $\begin{array}{l}\text { Nomor } \\
\text { Butir }\end{array}$ & CITC & CAIID & Perlakuan \\
\hline 16 & 0.214 & 0.701 & Digugurkan \\
9 & 0.599 & 0.726 & Digugurkan \\
$9 \mathrm{~N}$ & 0.661 & 0.664 & Dipertahankan \\
18 & 0.363 & 0.662 & Digugurkan \\
$18 \mathrm{~N}$ & 0.461 & 0.701 & Dipertahankan \\
\hline
\end{tabular}

Peneliti juga melakukan analisis reliabilitas pada blueprint awal dari alat ukur DGS yang dapat dilihat pada tabel 10 . Semua dimensi dari DGS pada blueprint awal memiliki nilai alpha cronbach di atas 0.7 dan CITC di atas 0.3, kecuali pada dimensi Grace to Self. Alpha cronbach dari dimensi Grace to Self hanya mencapai 0.696, dengan rentang CITC dari 0.282 sampai 0.573 , sehingga hanya dapat dikatakan cukup reliabel.

Tabel 10. Reliabilitas blueprint awal

\begin{tabular}{|c|c|c|c|c|}
\hline \multirow[b]{2}{*}{ Nomor } & \multirow[b]{2}{*}{ Dimensi } & \multicolumn{3}{|c|}{ Hasil reliabilitas terbaik } \\
\hline & & $\begin{array}{c}\text { Alpha } \\
\text { cronbach }\end{array}$ & $\begin{array}{c}\text { Rentang } \\
\text { CITC }\end{array}$ & $\begin{array}{c}\text { Jumlah } \\
\text { Butir }\end{array}$ \\
\hline 1 & $\begin{array}{c}\text { Grace to } \\
\text { Others }\end{array}$ & 0.825 & $\begin{array}{c}0.457- \\
0.699\end{array}$ & 6 \\
\hline 2 & $\begin{array}{c}\text { Experiencin } \\
\text { g God's } \\
\text { Grace }\end{array}$ & 0.829 & $\begin{array}{c}0.377- \\
0.717\end{array}$ & 8 \\
\hline 3 & $\begin{array}{c}\text { Grace from } \\
\text { Others }\end{array}$ & 0.832 & $\begin{array}{c}0.493- \\
0.672\end{array}$ & 7 \\
\hline 4 & $\begin{array}{l}\text { Costly } \\
\text { Grace }\end{array}$ & 0.801 & $\begin{array}{l}0.332- \\
0.606\end{array}$ & 7 \\
\hline 5 & $\begin{array}{l}\text { Grace to } \\
\text { Self }\end{array}$ & 0.696 & $\begin{array}{c}0.282- \\
0.573\end{array}$ & 7 \\
\hline
\end{tabular}

Untuk mencapai nilai reliabilitas terbaik dari blueprint awal yang dapat dilihat pada tabel 10 , peneliti memberikan perlakuan kepada beberapa butir. Perlakuan butir pada analisis reliabilitas blueprint awal dapat dilihat pada tabel 11 .

Tabel 11. Perlakuan butir analisis reliabilitas blueprint awal

\begin{tabular}{llll}
\hline $\begin{array}{l}\text { Nomor } \\
\text { Butir }\end{array}$ & CITC & CAIID & Perlakuan \\
\hline $28^{*}$ & 0.052 & 0.832 & Digugurkan \\
$36^{*}$ & 0.139 & 0.825 & Digugurkan \\
\hline
\end{tabular}

Catatan: *=Reverse. Butir 28 dan 36 di-reverse terlebih dahulu karena nilai CITC awal menunjukkan angka negatif. 
Berikut adalah tabel spesifikasi 6 faktor setelah dilakukan analisis EFA dan akhir dari alat ukur DGS pengelompokkan reliabilitas.

Tabel 12. Tabel spesifikasi akhir alat ukur DGS

\begin{tabular}{|c|c|c|c|}
\hline \multirow[t]{2}{*}{ Dimensi } & \multicolumn{2}{|c|}{ Butir } & \multirow[t]{2}{*}{ Jumlah Butir } \\
\hline & Favorable & Unfavorable & \\
\hline $\begin{array}{c}\text { Experiencing God's } \\
\text { Grace }\end{array}$ & $1,2,3,4,5,6,7,8$ & - & 8 \\
\hline $\begin{array}{c}\text { Grace and } \\
\text { Responsibility }\end{array}$ & - & $9 \mathrm{~N}, 10,11$ & 3 \\
\hline $\begin{array}{l}\text { Graceful Avoidance of } \\
\text { Personal Legalism }\end{array}$ & - & $12,13,14,15$ & 4 \\
\hline Grace to Self & $18 \mathrm{~N}, 19,20,21$ & - & 4 \\
\hline Grace from Others & - & $\begin{array}{c}23,24,25,26,27 \\
27 \mathrm{~N}, 29\end{array}$ & 7 \\
\hline Grace to Others & $\begin{array}{c}- \\
\text { Total }\end{array}$ & $30,31,32,33,34,35$ & $\begin{array}{c}6 \\
32\end{array}$ \\
\hline
\end{tabular}

\section{Pembahasan}

Peneliti membandingkan pengelompokkan berdasarkan blueprint awal dan pengelompokan berdasarkan blueprint analisis faktor. Hasil dari EFA menunjukkan bahwa dimensi Costly Grace (CG) terbagi menjadi dua dimensi yaitu dimensi Grace and Responsibility (GR) dan Graceful Avoidance of Personal Legalism (GAPL). Hal ini dikarenakan Dimensi GR dan GAPL adalah dimensi dari alat ukur Richmont Grace Scale (RGS) yang awalnya membentuk dimensi CG.

Secara teori, Bonhoeffer juga menjelaskan adanya dua kesalahpahaman, yaitu bahwa kasih karunia tanpa menuntut ketaatan dan pertobatan, dan juga kasih karunia yang didapatkan melalui usaha manusia. Hal ini sejalan dengan butir-butir dari GR dan GAPL. Dimensi GR menjelaskan mengenai kesalahpahaman terhadap kasih karunia tanpa adanya ketaatan dan pertobatan. Sedangkan, butir-butir dalam GAPL mendeskripsikan tentang kesalahpahaman mengenai kasih karunia yang didapatkan melalui usaha manusia.

Peneliti kemudian membandingkan konsistensi internal dari dimensi-dimensi pada blueprint awal dan blueprint hasil analisis faktor. Semua dimensi memiliki alpha cronbach yang sama, kecuali pada dimensi Costly Grace (CG), Grace and Responsibility (GR), Graceful Avoidance of Personal Legalism (GAPL), dan Grace to Self (GTS). Pada dimensi CG, GR, dan GAPL memiliki alpha cronbach di atas 0.7 
dan CITC di atas 0.3 sehingga dapat dikatakan memiliki konsistensi internal.

Sedangkan, dimensi GTS pada blueprint hasil analisis faktor lebih baik dibandingkan dengan dimensi GTS blueprint awal. Hal ini dikarenakan dimensi GTS pada blueprint awal, memiliki alpha cronbach sebesar 0.696 dan rentang CITC dari 0.282 sampai 0.573 , sehingga hanya dapat dikatakan cukup reliabel. Namun, dimensi GTS pada blueprint hasil analisis faktor memiliki nilai alpha cronbach di atas 0.7 dan CITC di atas 0.3 , sehingga dapat dikatakan memiliki konsistensi internal yang baik.

\section{KESIMPULAN}

Blueprint awal dan blueprint hasil analisis faktor dari DGS mempunyai pengelompokkan yang baik. Namun, peneliti meyakini bahwa pengelompokkan enam faktor dari alat ukur DGS versi Indonesia sebagai pengelompokkan terbaik dikarenakan secara pengelompokkan 9 maupun 6 faktor dan secara teori dimensi CG memang terbagi menjadi dua dimensi yang mendeskripsikan dua kesalahpahaman kasih karunia yaitu dimensi GR dan dimensi GAPL. Peneliti menyimpulkan bahwa DGS valid berdasarkan sumber bukti struktur internal dan dapat digunakan untuk mengukur pengalaman, keyakinan, dan sikap pada orang Kristen di Indonesia secara akurat. Namun, alat ukur DGS tidak dapat digunakan untuk beberapa orang Kristen dengan aliran seperti hyper grace atau hypo grace. Aliran-aliran tersebut menganut teologi mengenai cheap grace dalam pengajaran mereka, sehingga tidak sesuai dengan alat ukur DGS yang menolak pengajaran mengenai cheap grace.

\section{REKOMENDASI}

Pada penelitian selanjutnya, peneliti mengusulkan alat ukur DGS versi Indonesia dengan pengelompokkan 6 faktor. Peneliti merekomendasikan untuk menggunakan sumber bukti validitas yang lain selain struktur internal. Kemudian, peneliti juga menyarankan untuk menggunakan metode CFA untuk mengecek kesesuaian pengelompokkan butir dengan a priori atau teori dari DGS. Selain itu, untuk meningkatkan keakuratan terjemahan, peneliti menyarankan untuk melakukan metode back translation.

\section{UCAPAN TERIMA KASIH}

Penulis pertama mengucapkan terima kasih yang sebesar-besarnya kepada penulis kedua, Lina Natalya, S.Psi., M.Si., dan kepada penulis ketiga, Dr. Ide Bagus Siaputra S.Psi. Penulis kedua sangat membantu penulis pertama dalam mengecek naskah, teori, pengambilan data, serta mengartikan butir alat ukur DGS dari 
bahasa Inggris menjadi bahasa Indonesia.

Penulis ketiga juga membantu penulis pertama dalam pengecekkan artikel serta penentuan subjek dalam pengambilan data. Tanpa kontribusi penulis kedua dan ketiga, penulis pertama tidak dapat mewujudkan artikel ini.

\section{DAFTAR PUSTAKA}

Azwar, Saiffudin. Reliabilitas Dan Validitas. 3rd ed. Yogyakarta: Pustaka Pelajar, 2012.

Bonhoeffer, Dietrich. The Cost of Discipleship. London: SCM Press Ltd, 2015.

Bufford, Rodger K., Timothy A. Sisemore, and Amanda M. Blackburn. "Dimensions of Grace: Factor Analysis of Three Grace Scales." Psychology of Religion and Spirituality 9, no. 1 (2017): 56-69.

Elwell, Walter A. Evangelical Dictionary of Theology. USA: Baker Publishing Group, 2001.

Emmons, Robert A., Peter C. Hill, Justin L. Barrett, and Kelly M. Kapic. "Psychological and Theological Reflections on Grace and Its Relevance for Science and Practice." Psychology of Religion and Spirituality 9, no. 3 (August 1, 2017): 276-284. Accessed August 5, 2020. /record/2017-35611-005.

McMinn, Mark R., Janeil N. Ruiz, David Marx, J. Brooke Wright, and Nicole B. Gilbert. "Professional Psychology and the Doctrines of Sin and Grace: Christian Leaders' Perspectives." Professional Psychology: Research and Practice 37, no. 3 (June 2006): 295-302.
Natalya, Lina. "Struktur Internal." In Teori Dan Praktik Cara Asyik Belajar Pengukuran Psikologis. Surabaya: Centre of Lifelong Learning, 2016.

Natalya, Lina, and Cynthia Vivian Purwanto. "Exploratory and Confirmatory Factor Analysis of the Academic Motivation Scale (AMS)Bahasa Indonesia." Makara Human Behavior Studies in Asia 22, no. 1 (July 27, 2018): 29.

Piper, John. Five Points: Towards a Deeper Experience of God's Grace. Scotland: Christian Focus Publication, 2013.

Purwanto, Cynthia Vivian, and Lina Natalya. "Tomorrow Will Always Come, I Am a Last-Minute Person: Validation of the Active Procrastination Scale-Bahasa Indonesia." Makara Human Behavior Studies in Asia 23, no. 1 (July 31, 2019): 46.

Sells, James N., and Mark A.Yarhouse. Counseling Couples in Conflict. USA: Inter-Varsity Press, 2011.

Singh, Kultar. Quantitative Social Research Methods. New Delhi: Sage Publications Pvt Ltd, 2007.

Sisemore, Timothy, Matthew Arbuckle, Melinda Killian, Elizabeth Mortellaro, Mahogany Swanson, Robert Fisher, and Joshua McGinnis. "Grace and Christian Psychology-Part 1: Preliminary Measurement, Relationships, and Implications for Practice." Edification: The Transdisciplinary Journal of Christian Psychology 4, no. 2 (2011): 57-63.

Tjeltveit, Alan. "Understanding Human Beings in the Light of Grace: The Possibility and Promise of TheologyInformed Psychologies." Consensus 29, no. 2 (2004): 5. 
Tobias, Sigmund, and James E. Carlson. "Brief Report: Bartlett's Test of Sphericity and Chance Findings in Factor Analysis." Multivariate Behavioral Research 4, no. 3 (July 1, 1969): 375-377. Accessed August 6, 2020.

https://www.tandfonline.com/doi/abs/ 10.1207/s15327906mbr0403_8.

Torrance, T. F. "Cheap and Costly Grace." Baptist Quarterly 22, no. 6 (January 1968): 290-312. Accessed August 5, 2020.

https://www.tandfonline.com/doi/abs/ 10.1080/0005576X.1968.11751246.

Utami, Meinarini Catur. "Analisis Faktorfaktor yang Mempengaruhi Dosen dalam Melanjutkan S3 dengan Metode Principal Component Analysis (Studi Kasus: Program Studi SI/TI FST UIN)." Jurnal Sistem Informasi 6, no. 1 (April 19, 2013): 1-7. Accessed
August

6 ,

2020.

http://journal.uinjkt.ac.id/index.php/si steminformasi/article/view/313.

Wiktorowicz, Justyna. "Exploratory Factor Analysis in the Measurement of the Competencies of Older People." Ekonometria, no. 54 (2016): 48-60.

WOM, and Cynthia Vivian. Purwanto. "Panduan Analisis Data." In Teori Dan Praktik Cara Asyik Belajar Pengukuran Psikologis. Surabaya: Centre of Lifelong Learning, 2016.

Zaluchu, Sonny Eli. "Strategi Penelitian Kualitatif Dan Kuantitatif Di Dalam Penelitian Agama." Evangelikal: Jurnal Teologi Injili dan Pembinaan Warga Jemaat 4, no. 1 (2020): 28-38. Accessed April 4, 2020. https://journal.sttsimpson.ac.id/index. php/EJTI/article/view/167. 